\title{
Effect of He:Ne laser on the growth of Amnion cells grown over a synthetic nanoscaffolds
}

\author{
Soheir Korraa ${ }^{1}$, M.B.S. ${ }^{2}$ and Eman El Sheikh ${ }^{2}$, Hassan Abdel Rehim ${ }^{3}$ \\ ${ }^{1}$ Health Radiation Research - National Center for Radiation Research - Atomic Energy Authority \\ ${ }^{2}$ Physics department, Women`s College for arts, science and education, Ain Shams University. \\ ${ }^{3}$ Chemistry department --National Center for Radiation Research - Atomic Energy Authority-
}

\begin{abstract}
:
Human amnion cells are very important type of stem cells, which are able to differentiate into cell types of all three germ layers, so this study was investigated the impact of He-Ne laser on viability, proliferation and differentiation of cultured human amnion cells grown over a synthetic nanoscaffold. This nanoscaffold was prepared from 13\% polycaprolactone (PCL) dissolved in 1:1 chloroform: dimethyle formamide (DMF) as a solvent by using electrospinning technique. Human amnion cells were grown over the scaffold and were exposed to He:Ne laser at doses 1, 2.5 and $5 \mathrm{~J} / \mathrm{cm}^{2}$ every 48 hours for a duration of 12 days. It was concluded that scanning electron microscope (SEM) photographs showed good colony spreading of seeded amnion cells grown over the electrospun scaffold, and He:Ne laser induced cell proliferation as detected by MTT, nitric oxide and lipid peroxidation production.
\end{abstract}

\section{Key Words: Synthetic nanoscaffolds / Aminon cells / He:Ne laser Irradiation.}

\section{Introduction:}

Human amniotic membrane (HAM) has been used for the treatment of wounds since 1910 . The low immunogenicity of HAM permits its allogeneic use and it acts as a physical barrier against bacterial contamination and also creates a moist environment required for healing. Furthermore, it reduces pain and has anti-inflammatory, anti-fibrotic, and anti-microbial activities that are beneficial for wound healing (Niknejad et al., 2008). Such amniotic membranes rich in HAECs compose the inner surface of the amnion (Parolini et al., 2008; Miki et al., 2005) and are able to differentiate into cell types of all three germ layers (Ilancheran et al., 2007; Bailo et al., 2004) including neuronal cells, smooth muscle, cardiomyocytes, osteocytes, adipocytes, hepatocytes, and pancreatic cells (Miki et al.,2005 ; Murphy et al.,2012). HAECs can be induced to differentiate into lung epithelium-like cells in vitro (Ilancheran et al., 2007). Unlike other pluripotent cells, such as embryonic stem cells, HAECs do not form teratomas (Miki et al., 2005). Despite these benefits, the widespread use of fresh tissue has been limited due to its short shelf life and the risk of disease transmission associated with insufficient time for testing (Adds et al., 2001). Therefore, different preservation and technology techniques have been developed to overcome these limitations.

Corresponding author: Bntelsheikh@yahoo.com 
One approach is tissue engineering which consists of seeding appropriate cells on a biodegradable scaffold, stimulating cell growth and differentiation in vitro, and then implanting the engineered complex in vivo to achieve functional tissue (Kreisler et al., 2002;

AlGhamdi et al., 2012).

It has been suggested that the energy of the laser is absorbed by intracellular chromophores and converted into metabolic energy, which is then used by the mitochondrial respiratory chain to produce ATP and increase DNA activity and the synthesis of RNA and proteins (Benedicenti et al., 2008). Laser irradiation at a wavelength of $632.8 \mathrm{~nm}$ induced the prolipheration of fibroblasts in culture (Al-Watban and Andres, 2012). Higher production of fibroblast growth factor has been shown, when fibroblasts were irradiated with a 660-nm laser beam (Yu et al., 1994). Furthermore, laser light of 632.8nm was found to increase cell proliferation in keratinocyte cultures (Steinlechner et al., 1993) and to stimulate the secretion of cytokines IL-1 and IL-8 (Yu et al., 1996). It has also been observed higher proliferation, differentiation, and maturation of osteoblasts when respectively irradiated at 632.8 and 670nm (Stein et al., 2005; Stein et al., 2008).

The primary aim of this research was to investigate the impact of fabricated electrospun nanoscaffold, on viability and differentiation of cultured human amnion cells. In this respect, the nanoscaffold was prepared from 13\% polycaprolactone (PCL) dissolved in 1:1 chloroform: dimethyle formamide (DMF) as a solvent by using electrospinning technique.

\section{Material and methods:}

\section{a) Scaffolds preparation and cell culture:}

All aseptic procedures regarding preparation of scaffolds were respected and cell cultures were prepared in a clean room facility of Tissue Culture Laboratory at the National Center for Radiation Research and Technology, Egyptian Atomic Energy Authority.

1. Amnion cells:

Cells were amnion cells purchased from Center for Vaccination and Sera (Vacsera) Egypt.

2. Electrospun scaffolds:

Electrospun nanoscaffold was prepared from $13 \%$ polycaprolactone (PCL) dissolved in 1:1 chloroform: dimethyle formamide as a solvent by using Nano Fiber Electrospinning Unit at the National Center for Radiation Research and Technology, Egyptian Atomic Energy Authority. For the cell culture procedure, the scaffolds were cut into $12 \mathrm{~mm}$ disks, sterilized by 25 Kilogray ionizing radiation(gamma rays).

3. Amnion cell layer preparation:

Culture medium DMEM with minimal glucose (MP Biomedical) $+2 \%$ foetal bovine serum (MP Biomedical), penicillin (100 IU/ml), streptomycin $(100 \mu \mathrm{g} / \mathrm{ml})$, gentamycin $(50 \mu \mathrm{g} / \mathrm{ml})$ (Sigma - Aldrich) was changed every three days (Chen et al., 2013). Cells were passaged at confluence of $70 \%$ by incubation with $0.05 \%$ trypsinEDTA (Sigma, Aldrich) for 5 minutes at $+37^{\circ} \mathrm{C}$. Trypsin was neutralized with the FM media and by centrifugation for $5 \mathrm{~min}$ at $1100 \mathrm{rpm}$.

\section{b) Laser-irradiation:}

Cells grown on scaffolds were irradiated with He: Ne laser at power output of $15 \mathrm{~mW}$, wavelength of $632 \mathrm{~nm}$, and doses of $1,2.5$ and $5 \mathrm{~J} / \mathrm{cm}^{2}$ every 48 hours for a duration of 12 
days. For laser irradiation, the probe was directed perpendicular to each plate at a distance of $2 \mathrm{~cm}$ from the cells. The cells were plated in such a way that was one well, between the seeded wells, was left empty to prevent the unintentional dispersion of light between wells during laser irradiation.

\section{c) Scanning electron microscope (SEM):}

For morphological examination, cells-materials complex were fixed with $1.5 \%$ glutaraldehyde (Fisher Scientific, US) for $30 \mathrm{~min}$. The samples were exposed to $2 \%$ osmium tetroxide (Sigma-Aldrich, US) for $30 \mathrm{~min}$. Following rinse in distilled water, they were dehydrated through a graded series of ethanol $(50,70,90$, and $100 \%)$ for $2-5 \mathrm{~min}$. The dehydration was completed in hexamethyl disilazane (Fluka, Germany) for 10 minutes. After air-drying and sputter coating with gold, the cells morphology on the PCL-HA scaffold was evaluated by using JSM-5400 Scanning Electron Microscope at $10 \mathrm{kV}$.

\section{d) Viability tests:}

\section{Assessment of Cell Viabilities and Functions on Scaffolds}

1. The methyl-tetrazolium assay (MTT) was used for the assessment of cell viability. This is a colorimetric assay which has been established as a reliable method of assessing cell viability. MTT, $20 \mu \mathrm{l}$ dissolved in phosphate buffered saline $(5 \mathrm{mg}$ MTT/ml phosphate buffered saline), was added to the cells. After 4-hour incubation at $37^{\circ} \mathrm{C}$, culture medium containing MTT was removed, $100 \mu$ dimethylsulphoxide (DMSO) was added to solubilize the blue formazan formed by the viable cells. The plates were read at $570 \mathrm{~nm}$ by an ELISA plate reader (Berridg and Tan, 2001).

2. Measurement of NO, The production of NO by He-Ne laser stimulated neutrophils was determined by the Griess reaction (Miranda et al., 2001). Briefly, the Griess reagent was made by mixing equal volumes of $5 \%$ orthophosphoric acid containing $1 \%$ sulfanilamide and $0.1 \%$ napthylethylenediamine and was kept at $4{ }^{\circ} \mathrm{C}$ until used. Triplicates of $50 \mu \mathrm{l}$ of culture supernatant or standards of serially diluted sodium nitrite were added to 96-well Immulon 4 microtiter plates, and $50 \mu 1$ of the Griess reagent supplemented with nitrate reductase (final concentration $0.1 \mathrm{U} / \mathrm{ml}$ ) was then added and optical density was measured spectrophotometrically at $570 \mathrm{~nm}$ using a microplate reader.

3. Thiobarbituric acid reactive substances assay, Concentration of thiobarbituric acid reactive substances (TBARS) was evaluated with an assay. BAL fluid was prepared to denaturate proteins with $50 \%$ trichloroacetic acid. The supernatants were transferred to a clean tube and $75 \mu \mathrm{l}$ of $1.3 \%$ thiobarbituric acid (Sigma Chemie, Deisenhofen, Germany) in $0.3 \% \mathrm{NaOH}$ were added. After incubation for $1 \mathrm{~h}$ at $90^{\circ} \mathrm{C}$ and subsequent cooling in ice water, samples were centrifuged for 6 min. Finally, $200 \mu 1$ of sample were transferred to a 96-well plate and the absorbance, at $530 \mathrm{~nm}$, was read in a microplate reader (Dynex Technologies, Denkendorf, Germany). TBARS were quantified by using a standard curve of malondialdehyde (Sigma Chemie, Germany)

(Dorota et al., 2011). 


\section{Results and Discussion}

\subsection{Results}

It is clear that there is more adherence of cells on scaffolds during different time of cell culture and at the end of the twelve's day laser irradiated cells were more compact on the scaffolds.The morphological appearance of the electrospun $13 \%$ polycaprolactone (PCL) dissolved in 1:1 chloroform: dimethyle formamide as a solvent, as shown on the SEM images (Figure 1), confirmed high non-uniformity of the fibers.
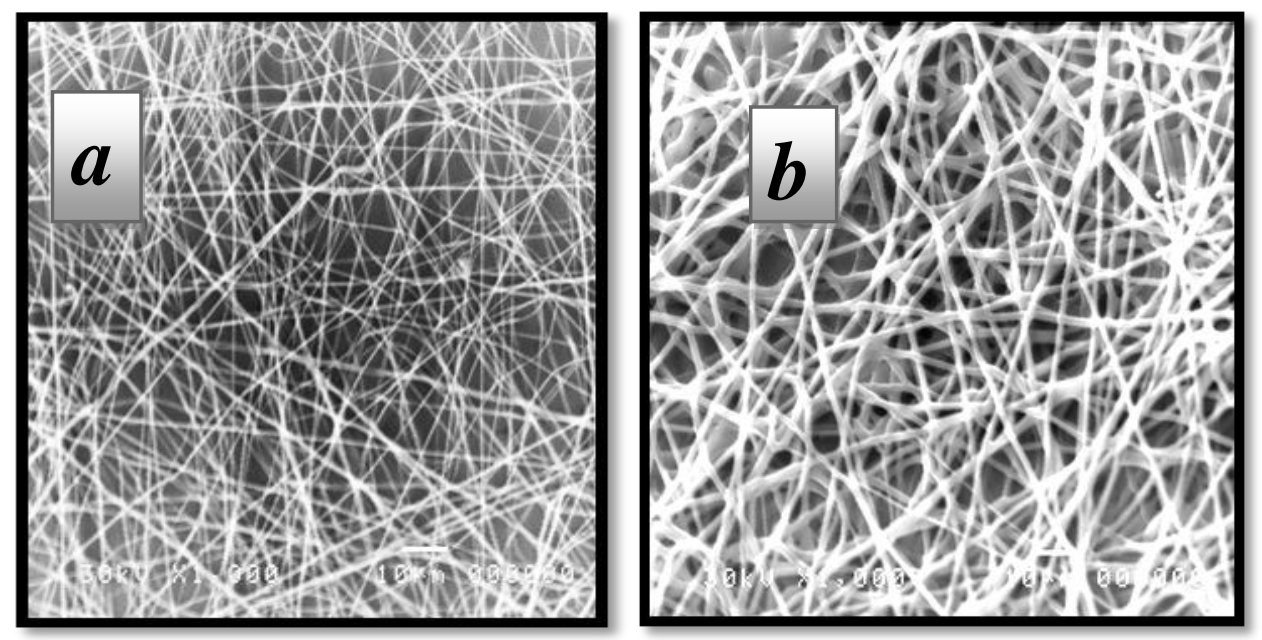

Figure 1: Scanning electron microscope (SEM) graphs for 13\% electrospun PCL dissolved in 1:1 chloroform: dimethyle formamide (DMF) as a solvent [magnification 1000(a), 2000(b)].

In figure 1, the total ranges of the fiber diameters were between $100 \mathrm{~nm}$ and almost $2 \mu \mathrm{m}$, with thicker fibers having lower quantities. Similarly, the top pore opening area distributions were in the range between $2 \mu \mathrm{m}^{2}$ to $30 \mu \mathrm{m}^{2}$, with much lower number of observed wider pore openings.
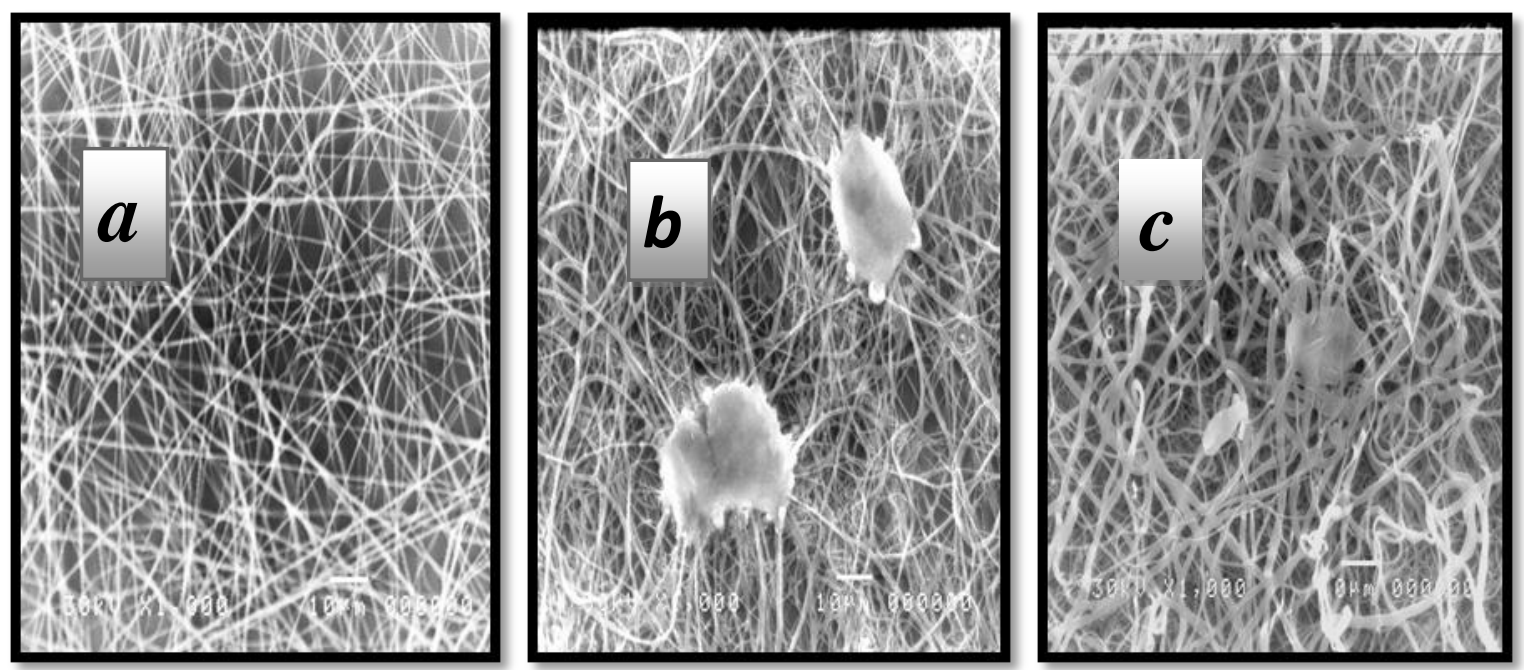

Figure 2: SEM graphs of Amnion grown over PCL nanoscaffolds (a before, b after 2 days, c after 12 days). 

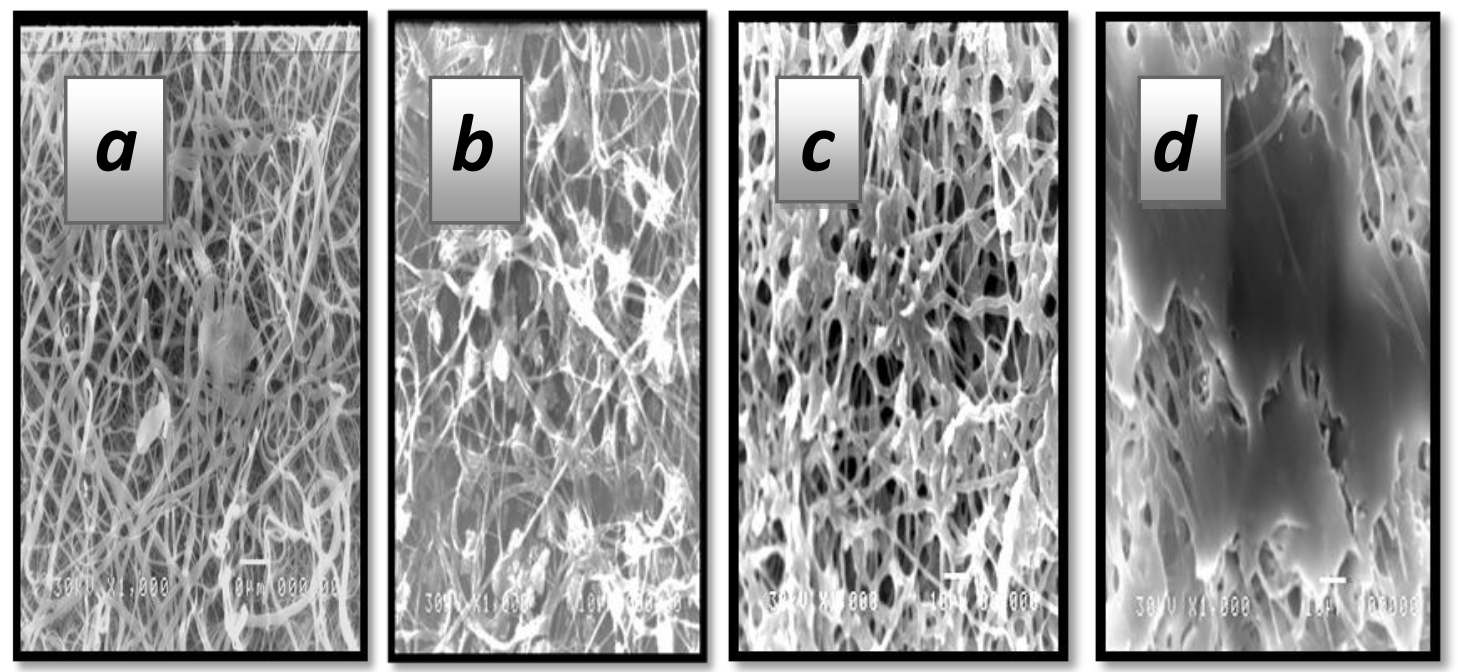

Figure 3: SEM graphs of Amnion cells grown over PCL nanoscaffolds (a after 12 days and not exposed to laser; b,c,d after 12 days and exposed to He:Ne laser at 1, 2.5 and $5 \mathrm{~J} / \mathrm{cm}^{2}$, respectively).

\section{Biochemical Tests:}

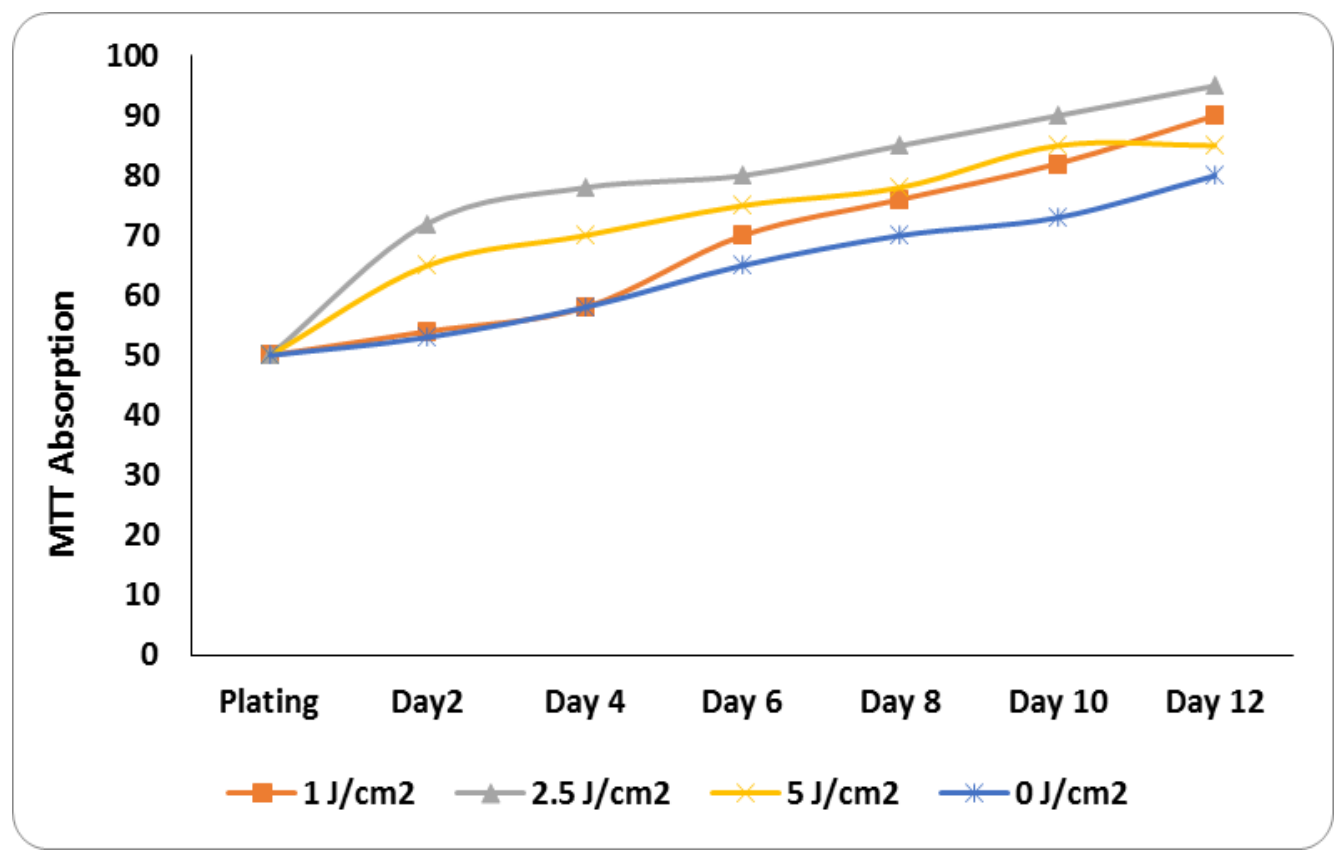

Figure 4: Absorbance of Microculture Tetrazolium Test (MTT assay) from amnion cells grown on PCL nanoscaffolds with and without different doses of He:Ne laser irradiation. 


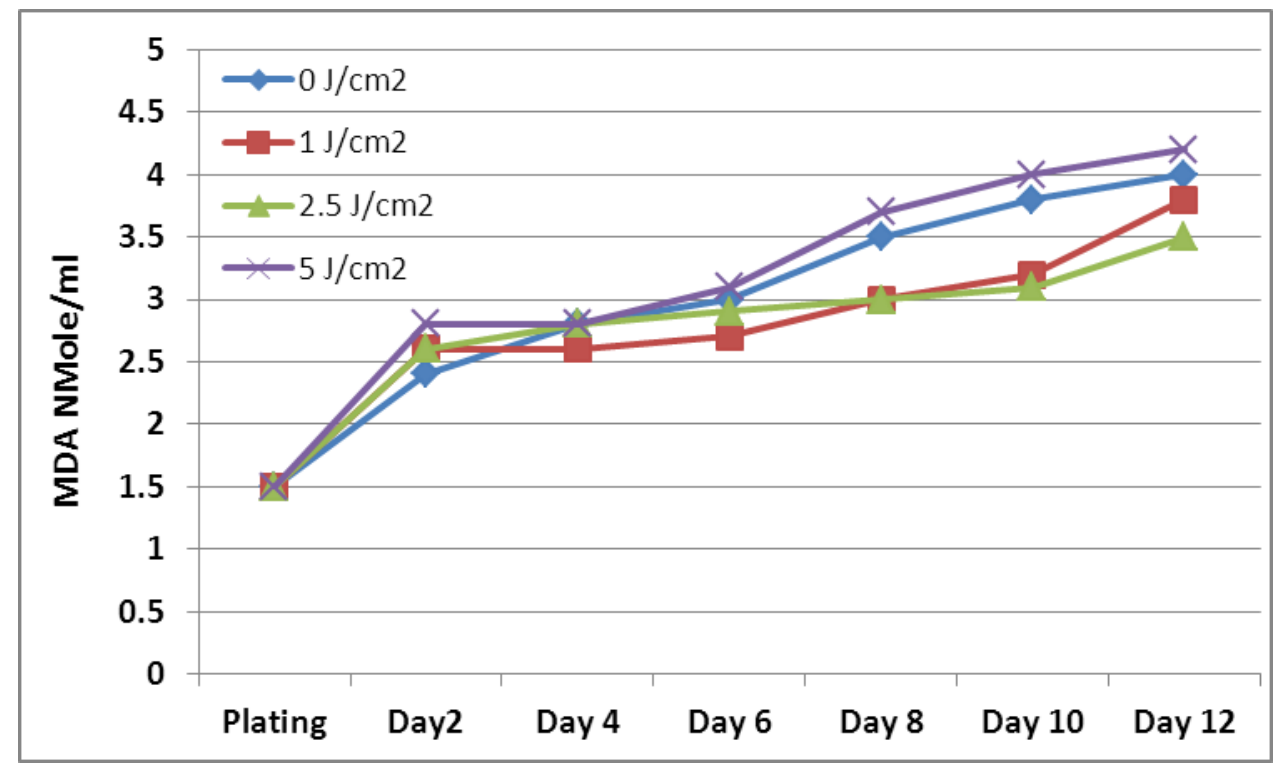

Figure 5: Metabolites: Malondialdehyde in culture media of amnion cells grown on PCL nanoscaffolds with and without different doses of $\mathrm{He}: \mathrm{Ne}$ laser Irradiation.

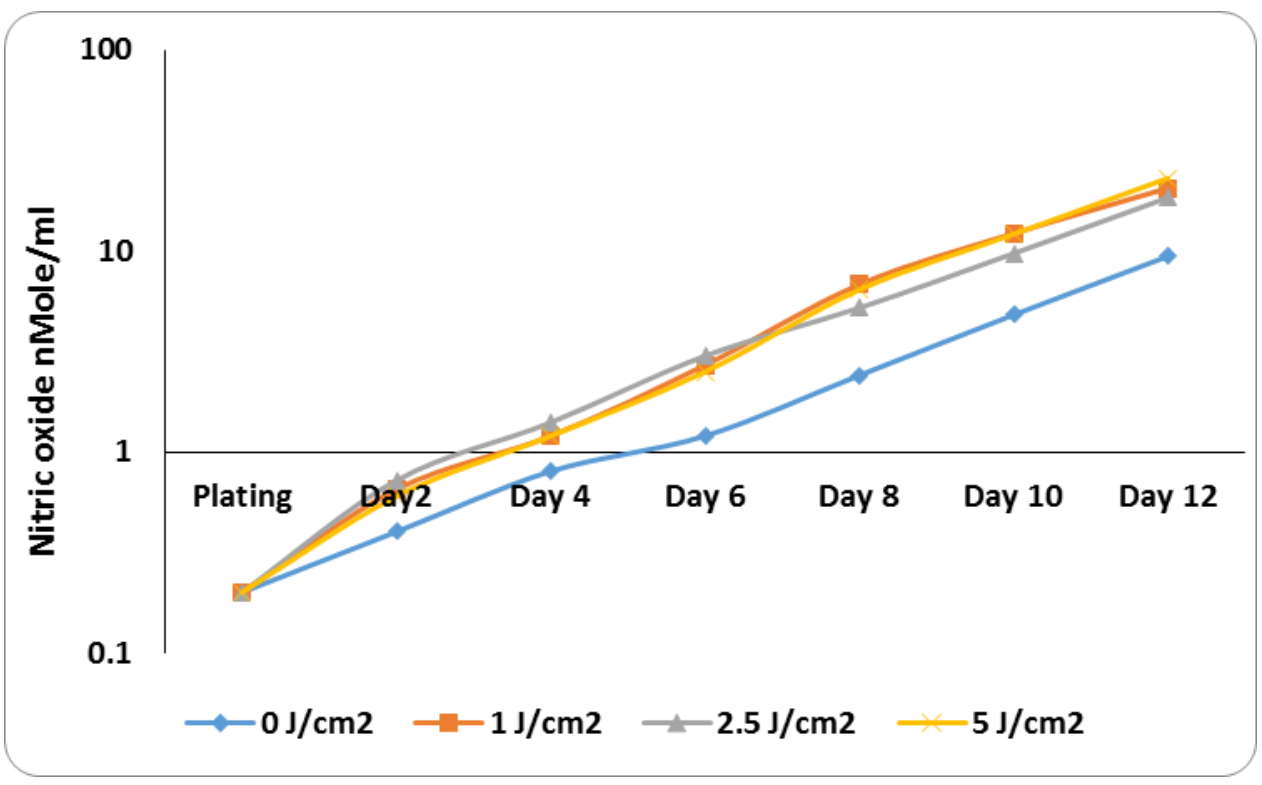

Figure 6: Metabolites: Nitric oxide in culture media of amnion cells grown on PCL nanoscaffolds with and without different doses of He:Ne laser Irradiation.

\section{Discussion}

Synthetic materials enable better control of scaffold mechanics, geometry, porosity, and rate of degradation. Scaffolds with porous structure and specified architecture allow, by different size and distribution of pores, spatially oriented cell proliferation and provide desired three- 
dimensional tissue-equivalent. Nanoscaffolds produced from nanofibers show advantages of high porosity and surface to volume ratio. They are also biocompatible, cost-effective, and easy to design according to custom needs (Vasita and Katti, 2006). For a scaffold to provide not only cell attachment, but also in-depth penetration, pores above several tenths of $\mu \mathrm{m}$ in diameter are a necessity (Skotak et al., 2011). 13\% Polycaprolactone dissolved in 1:1 chloroform: DMF was neutral. It did not change PH value of water and did not change color of media used for cell culture. It did not swell nor fade and were persistent during the applied culture period up to 12 days. Sterilization by $25 \mathrm{KGy}$ of Gamma radiation did not change their physical nor chemical properties.

Figure 4 showed that He:Ne laser enhanced cell growth over scaffolds by irradiating the scaffolds in culture with He:Ne laser doses 1, 2.5 and $5 \mathrm{Jcm}^{2}$ day after day. Exposure to low level laser is known to enhance the growth, proliferation and differentiation of different types of cells in culture (Korraa, 2003). It has been suggested that the energy of the laser is absorbed by intracellular chromophores and converted into metabolic energy, which is then used by the mitochondrial respiratory chain to produce ATP and increase DNA activity and the synthesis of RNA and proteins (Shefer et al., 2002). It has been demonstrated that low level laser also induces higher levels of the anti-apoptotic protein Bcl-2 and lower amounts of the pro-apoptotic protein BAX thus inhibiting apoptosis (Shefer et al., 2002).

In figure 5, Lipid peroxidation was significantly decreased in the media of amnion cells grown on scaffolds after 12 days post culture compared to two days. This significant decreased in lipid peroxidation observed due to laser irradiation supports previous findings that LLLI (low level laser irradiation) induces a decrease in oxidative stress (Vin'cova et al., 1999). LLLI has been demonstrated to be a non-stressful treatment in vitro that induces the expression of the inducible heat shock protein, Hsp70 and Hsp90, which reforms denaturated proteins (Abou Hashieh et al., 1997; Novoselova et al., 2006). Studies have shown lately, that low-energy laser irradiation increased the level of superoxide dismutase enzyme and lowered the increase in lipid peroxidation associated with experimental ischemia and reperfusion, and human acute edema (Karageuzyan et al., 1998) and was shown in vivo and in vitro to reduce levels of lipid peroxidation (Iakymenko, 2001 ; Shirin Farivar et al., 2014).

In figure 6, Nitric oxide was significantly increased in the media 12 days post culture compared to two days. Laser is known to emit no heat, sound, or vibration. Instead of generating a thermal effect, LLLT acts by inducing a photochemical reaction in the cell, a process referred to as biostimulation or photobiomodulation. LLLT may cause the photodissociation of $\mathrm{NO}$ from intracellular stores and promotes the synthesis of deoxyribonucleic acid (DNA) and RNA and increases the production of proteins. It also modulates enzymatic activity, affects intracellular and extracellular $\mathrm{pH}$ and accelerates cell metabolism (EI Batanouny and Korraa, 2003). It is believed that the significant increase in NO generation, which is a scavenger of the superoxide anion, could be the cause for the observed decrease in oxidative stress which was induced post laser irradiation. It can be speculated that the shift in oxidant antioxidant balance induced by He: $\mathrm{Ne}$ laser leading to increased levels of NO stimulatory functions could be the cause to this decrease in markers of oxidative stress measured here in terms of lipid peroxidation (EI Batanouny and Korraa, 2003). 


\section{Conclusion:}

It was concluded that scanning electron microscope (SEM) photographs showed good colony spreading of seeded amnion cells grown over the electrospun nanoscaffold prepared from $13 \%$ polycaprolactone (PCL) dissolved in 1:1 chloroform: dimethyle formamide (DMF) as a solvent by using electrospinning technique and $\mathrm{He}: \mathrm{Ne}$ laser induced an increase in cell proliferation as detected by MTT, lipid peroxidation production and nitric oxide .

\section{References}

Abou Hashieh I, Tardieu C, Franquin JC,Helium neon laser irradiation is not a stressful treatment: a study on heat-shock protein (HSP70) level. Lasers Surg Med; 20:451-60(1997).

Adds PJ. Hunt CJ, Dart JK ,Amniotic membrane grafts, "fresh" or frozen? A clinical and in vitro comparison. Br J Ophthalmol; 85:905-907(2001).

AlGhamdi KM, Kumar A and Moussa NA. Low-level laser therapy: a useful technique for enhancing the proliferation of various cultured cells. Lasers Med. Sci.; 27(1):237-49(2012) Review.

Al-Watban FAH and Andres BL. Laser biomodulation of normal and neoplastic cells. Lasers Med Sci 27(5):1039-1043(2012).

Bailo M, Soncini M, Wengler GS and Parolini O. Engraftment potential of human amnion and chorion cells derived from term placenta. Transplantation; 78:1439-1448(2004).

Benedicenti S, Pepe IM, Angiero F and Benedicenti A. "Intracellular ATP level increases in lymphocytes irradiated with infrared laser light of wavelength $904 \mathrm{~nm}$. Photomed Laser Surg.26:451-453(2008).

Berridge $M$ and Tan A. Characterization of the cellular reduction of 3-(4,5-dimethylthiazol2-yl)-2,5-diphenyltetrazolium bromide (MTT): subcellular localization, substrate dependence, and involvement of mitochondrial electron transport in MTT reduction. Arch. Biochem Biophys 303(2):474-82(2001).

Chen Y. F., Dong Z., Jiang L., Lai D. and Guo L. Mouse primed embryonic stem cells could be maintained and reprogrammed on human amnion epithelial cells. Stem Cells Dev. 22, 320-329 (2013).

Dorota M., Olszewska-Słonina, Dariusz Musiałkiewicz, and Bogna Kowaliszyn. The concentration of thiobarbituric acid reactive substances (TBARS) and paraoxonase activity in blood of patients with osteoarthrosis after endoprosthesis implantation, Med Sci Monit. ; 17(9): CR498-CR504(2011).

El Batanouny M, Korraa SS. Nitric oxide (NO) and reactive oxygen species (ROS) inducible in human neutrophils by Low Intensity Laser: Effects on DNA-protein crosslink formation in lymphocytes. Arab J Lab Med; 29:59-68(2003). 
Shefer G, Partridge T, Heslop L, Gross J, Oron U and O. Halevy. Low-energy laser irradiation promotes the survival and cell cycle entry of skeletal muscle satellite cells. J. Cell Sci.; 115(7):1461-9(2002).

Iakymenko IL. Intensity of lipid peroxidation and concentration of free radicals in quail liver exposed to low-intensity laser irradiation to the embryo. Ukr Biokhim Zh; 73:87-90 (2001).

Ilancheran S, Michalska A, Peh G, Wallace EM, Pera M and Manuelpillai U. Stem cells derived from human fetal membranes display multilineage differentiation potential. Biol Reprod; 77:577-588(2007).

Karageuzyan KG, Sekoyan ES, Karagyan AT, et al. Phospholipid pool, lipid peroxidation, and superoxide dismutase activity under various types of oxidative stress of the brain and the effect of low-energy infrared laser irradiation. Biochemistry (Mosc); 63:1226-32(1998).

Kreisler M, Christoffers AB, Al-Haj H, Willershausen B and d'Hoedt B. Low-level 809$\mathrm{nm}$ diode laser-induced in vitro stimulation of the proliferation of human gingival fibroblasts. Lasers Surg Med.; 30(5):365-9 (2002).

Miki T, Lehmann T, Cai H, Stolz DB and Strom SC. Stem cell characteristics of amniotic epithelial cells. Stem Cells; 23:1549-1559(2005).

Miranda K, Espey $M$ and Wink D. A rapid, simple spectrophotometric method for simultaneous detection of nitrate and nitrite. J Nitric Oxide. 5(1): 62-71(2001).

Murphy SV, Lim R, Heraud P Jenkin G and Wallace EM. Human amnion epithelial cells induced to express functional cystic fibrosis transmembrane conductance regulator. PLoS One; 7:e46533. doi: 10.1371/journal.pone.0046533(2012).

Niknejad H, Peirovi H, Jorjani M, et al. Properties of the amniotic membrane for potential use in tissue engineering. Eur Cell Mater;15:88-99(2008).

Novoselova E, Cherenkov DA, Glushkova OV, et al. Effect of low-intensity laser radiation $(632.8 \mathrm{~nm})$ on immune cells isolated from mice. Biofizika; 51:509-18 (2006).

Parolini O, Alviano F, Bagnara GP, Bilic G, Buhring HJ, Zisch A and Strom SC. Concise review: isolation and characterization of cells from human term placenta: outcome of the first international Workshop on Placenta Derived Stem Cells. Stem Cells; 26:300311(2008).

Korraa. S. Role of Free Radicals in Low Energy Laser - Irradiation (LELI) Induced Photobiological Effects. The Millennium Laser Book Trilogy editor Zlatko Simunovic, Nomen NESCIO IOS Press, Nieuwe Hemwg 6B, 1013 BG Amsterdam, Netherlands(2003).

Shirin Farivar, Talieh Malekshahabi, and Reza Shiari. Biological effects of Low Level Laser Therapy, J Lasers Med Sci.; 5(2): 58-62 (2014).

Skotak M, Ragusa J, Gonzalez D and Subramanian A. Improved cellular infiltration into nanofibrous electrospun cross-linked gelatin scaffolds templated with micrometer-sized polyethylene glycol fibers. Biomed Mater. ; 6:055012(2011). 
Stein A, Benayahu D, Maltz $\mathbf{L}$ and Oron U. Low-Level laser irradiation promotes proliferation and differentiation of human osteoblasts in vitro. Photomed Laser Surg.; 23(2):161-6 (2005).

Stein E, Koehn J, Sutter W, Wendtlandt G, Wanschitz F, Thurnher D, et al. Initial effects of low-level laser therapy on growth and differentiation of human osteoblast-like cells. Wien Klin Wochenschr.; 120(3-4):112-7(2008).

Steinlechner C and Dysonm M. The effects of low-level laser therapy on the proliferation of keratinocytes. Laser Ther. ; 5:65-73 (1993).

Vasita R, Katti DS. Nanofibers and their applications in tissue engineering. Int $\mathbf{J}$ Nanomedicine; 1:15-30 (2006).

Vin'cova GA, Ionin AP, Ionin GI. The treatment of post traumatic uveitis with lowintensity laser radiation. Vestn Oftalmol; 115:209-1 (1999).

Yu HS, Chang KL, Yu CL, Chen JW and Chen GS. Low-energy helium-neon laser irradiation stimulates interleukin-1 alpha and interleukin-8 release from cultured human keratinocytes. J Invest Dermatol; 107 (4):593-6(1996).

Yu W, Naim JO and Lanzafame RJ. The effect of laser irradiation on the release of bFGF from 3 T3 fibroblasts. Photochem Photobiol. ; 59 (2):167-70 (1994). 


\section{الملخص باللغة|لعربية}

\section{تأثير الهيليوم- نيون ليزر على نمو الخلايا المشيمية المزروعةعلى دعامة صناعية نانومترية}

$$
\begin{aligned}
& \text { سهير قر اعة* ــ مسر ات بكر صديق عثمانـ- ايمان الثيخ - حسن عبد الرحيم* } \\
& \text { - المركز القومى لبحوث وتكنولوجيا الاشعاع_هيئة الطاقة الذرية - } \\
& \text { قسم الفيزياء-كلية البنات للأداب و العلوم و التربية- جامعة عين شمس }
\end{aligned}
$$

تساعد الخلايا المشيمية التى تحيط بالجنين البشرى على التئام الجروح.و هذا النوع من الخلايا لها القدرة

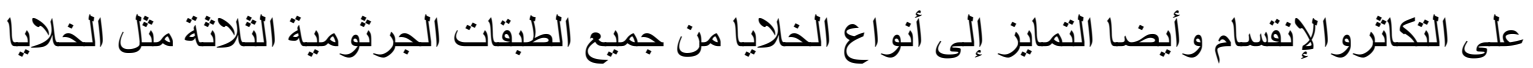
العصبية و العضلية و الخلايا المكونة للعظم و البنكرياس و غير ها ونظر الأهمينها صُمدت هذه الدراسة لمعرفة مدى تأثثر الهيليوم - نيون ليزر بجرعات مختلفة على نمو هذا النوع من الخلايا المزروعة على لئ دعامة البولي كابرو لاكتون النانومترية المصنعة باستخدام جهاز الغزل الكهربائى وذللك بتحضير تركيز

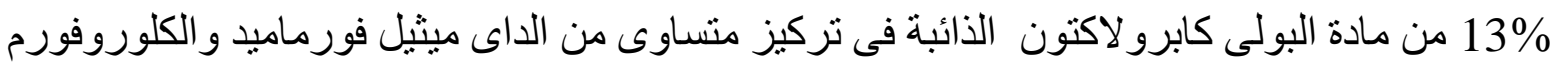
و وقد أوضحت النتائج أن الليزر له تأثيره الإيجابى على سرعة نمو الخلاياو التصاقها بالدعامة وذلك من خلال الصور الناتجة عن الميكروسكوب الإكترونى وأيضا على سر عة تكاثر الخلايا المُستدل عليه بو اسطة بعض التجارب البيولوجية. 
